\title{
A Comparison of Middle School Students Steps Per Minute (SPM) in Five Physical Education Curriculum Units Utilizing Pedometers: An Overall Contribution to Attaining the Recommended Step Counts Per Day in Children 以計步器為测量工具，比較五種體育活動 對中學生每日建議步走量之影響
}

\author{
David Barney \\ Brigham Young University, U.S.A. \\ Francis T. PLEBAN \\ Wayne State University, U.S.A. \\ Jenny PLEBAN \\ Wayne State University, U.S.A. \\ Justin DeKUPIER \\ Wayne State University, U.S.A.
}

\begin{abstract}
The purpose of this study was to compare pedometer steps per minute from five different curriculum units (basketball, volleyball, indoor soccer, pickle ball, and fitness activities) in middle school physical education classes as they relate to contributing to the recommended 12,000 to 16,000 steps per day for healthy children. Two hundred and thirty-two male and female middle school students participated in this study, 115 males and 117 females, respectively. Steps per minute were measured with pedometers in five curriculum units in middle school physical education classes; over 36 minutes of activity time. Overall, physical education classroom activities such as basketball, volleyball, indoor soccer, pickle ball, and fitness activities, measured during a 36 minute class timeframe, accounted for approximately $1 \%$ - $6 \%$ of the overall minimum 12,000 steps per day reported as appropriate for healthy children. Pedometers are becoming a useful tool for physical educators to compare sport activity levels in achieving the desired 12,000 to 16,000 steps a day for middle school children. With some modifications, physical educators can educate students and parents alike regarding pedometer use in helping to achieve recommended levels of physical activity and prescribed steps per day.
\end{abstract}

\section{摘 要}

目的：本研究的目的在比較五種體育活動 (籃球、排球、室內足球、酸菜球、健身活動) 對中學生每日建議步走量 $(12,000$ 步至16,000步) 的影響。研究方法 : 本研究以232名中學生為受試對象 (115男、117女)，以計步器為測量工具、36 分鐘為活 動長度, 測量中學生在五種不同的體育活動 (籃球、排球、室內足球、酸菜球、健身活動) 中每分鐘的步走量。研究結果：36 分鐘的體育活動(籃球、排球、室內足球、酸菜球、健身活動) 學生大約步走了 $1 \%$ 至 $6 \%$ 每日最低建議步走量 12000 步)。結 論：計步器是一個很好的測量工具, 中學體育教育者使用它來測量學生在不同程度的體育活動中的步走量, 並且比較五種體育活 動對中學生每日建議步走量的貢獻。經由適當的修正, 教育者可教導學生和家長使用計步器為工具, 用來幫助學生達到建議的體 育活動量以及每日建議步走量。 


\section{Introduction}

Generally, youth are one of the most active segments of the US population; however they also have become increasingly sedentary; leading to an epidemic of obesity, orthopedic issues, and metabolic syndrome. For the past three decades obesity has more than tripled for youth aged 6 to 11 years and doubled in youth 12 to 19 (Committee on Prevention of Obesity in Children and Youth, 2005). The 2003-04 National Health and Nutrition Examination Survey found that $18.8 \%$ of 6 to 11 year old youth and $17.4 \%$ of 12 to 19 year old youth were overweight (for both BMI at or above the $85^{\text {th }}$ percentile but less than 95 percentile for age and gender) (Ogden, Carroll, \& Curtain, 2006). Additionally, it is estimated that between $40 \%$ to $70 \%$ of obese children will become obese adults (Jain, 2004). The National Association for Sport and Physical Education (NASPE) has recommended that 60 minutes of physical activity should be accumulated per day (Corbin \& Pangrazi, 2004); with physical activity defined as exercise, sport, dance, as well as other movement forms.

One segment of a child's day where they can get a portion of their 60 minutes of physical activity is during their school's physical education class. To facilitate attaining 60 minutes of physical activity per day, Pate et al. (2006), have suggested that $50 \%$ of a student's physical education class time should be spent in activity time. So, theoretically middle school students should attain approximately 20 to 25 minutes of physical activity during a standard physical education class. However, how much does facilitating this classroom physical activity account for reaching a child's recommended total steps per day?

Another method of monitoring a child's daily physical activity level is to count the number of steps per minute utilizing a pedometer; with current research promoting 10,000 steps a day (Hatano, 1993 \& Hellmich, 1999). However, continuous research has segmented step counts per day based on specific populations. Currently children 8 to 10 years of age should attain 12,000 to 16,000 steps a day; 7,000 , to 13,000 steps a day for healthy younger adults; 6,000 to 8,500 steps a day for healthy older adults; and 3,500 to 5,500 steps a day in individuals with disabilities and chronic diseases (Tudor-Locke, \& Meyers, 2001).
Pedometers have been shown to be a valid and reliable method for measuring student activity in physical education (Beighle \& Pangrazi, 2006; Barfield, Rowe, \& Michael, 2004 \& Easton, Rowlands \& Ingledew, 1998). Furthermore, pedometers have been found to be very practical, easy to use, and cost effective in the physical education class setting (Barfield, Rowe, \& Michael, 2004; Beighle, Pangrazi, \&Vincent, 2001 \& Welk, Corbin \& Dale, 2000).

Pedometers have been used in the past to investigate steps per minute in middle school physical education class. The investigator determined approximately $76 \%$ of males and $60 \%$ of the females were active $50 \%$ of the time in physical education class (Scruggs, 2007). For this reason, the purpose of this study was to compare steps per minute from five different curriculum units (basketball, volleyball, indoor soccer, pickle ball, and fitness activities) presented middle school physical education classes and determine how physical education step counts contributed to obtaining the recommended 12,000 to 16,000 steps per day for healthy children.

\section{Methods}

\section{Participants}

Two hundred and thirty-two male and female middle school students, residing in an upper, urban Midwestern state, participated in this study, 115 males and 117 females, respectively. All participants were currently enrolled in either sixth, seventh or eighth grades at the time of the study. Males and females were similar in regards to academic school standing and ethnicity, with all participants self-identifying their ethnicity as White/ Non-Hispanic.

Additionally, parental consent was obtained, as well as consent from the middle school principal and physical education teacher, before the study proceeded. All middle school students participating in this investigation were verbally informed of the purpose of the study and were made familiar with the pedometer at the study's onset. Students were assured that non-participation or withdrawal from this study would at no time affect their grade in their respective physical education class. Furthermore, University Institutional Review Board (IRB) permission to conduct this investigation was obtained and granted before the onset of the study and any data collection. 


\section{Pedometer Instrument}

The Yamax Digi-Walker LS 2525 was the pedometer chosen to collect student step counts. This pedometer model recorded the following information: step count, distance covered, calories burned, time spent in activity, and a digital clock.

\section{Procedures}

On the days of data collection, students were instructed by their teacher to attach their pedometer when they arrived to class, and reset them to zero. Afterwards the teacher would begin their lesson for the day, comprised of the following four elements: 1) an introductory activity, 2) fitness activities, 3) lesson focus, and 4) review. First, the teacher would have students participate in an introductory activity. The purpose of the introductory activity was to quickly transition students into a fitness activity. For example, students would jog, skip, jump rope or play a quick game of tag. This portion of the lesson usually took two to three minutes. The second portion of the lesson comprised fitness activities focusing on the development of physical fitness. For this portion of the lesson fitness stations were set up throughout the gymnasium. For example, each station was comprised of the following: push-ups, various stretches, mountain climbers, or exercise bands. This part of the lesson took approximately seven to eight minutes; instruction centering on developing such fitness components as flexibility, muscular strength, and cardiovascular endurance. The third portion of the class period focused on the specific lesson content. This portion of the lesson lasted approximately 20 to 22 minutes where students worked on skills, participated in modified games, or played in a game-like activity. For example, students could spend time focusing on improving certain aspects of a newly taught skill, or play a two-on-two basketball game. Finally, the class ended with some type of game or class review, comprising approximately five minutes. For example, at the end of class the teacher had students play a game or activity emphasizing what was taught in class, or gather the students together and review what was taught in the lesson (Darst \& Pangrazi, 2002).
Middle school physical education classes were typically 48 minutes in length. The investigators were interested in measuring the 36 minutes of actual activity time, Daily Activity Time (DAT). To ensure 36 minutes of activity time, students were given six minutes to change into their gym clothes, participated in 36 minutes of activity, and approximately six minutes to change back into their school clothes and prepare for their next class period. Pedometer step count data were collected over 12 different class periods. The literature has suggested eight separate times or eight separate class periods are sufficient for gathering data when working with youth in seventh through twelfth grades (Vincent \& Pangrazi, 2002).

When the class period was finished, students would retrieve their student record sheet and record the number of steps they took during the class period. When the students had finished filling out their step counts from the class period, they returned their student record to the teacher. Only the teacher and the researchers had access to the student record sheet.

\section{Data Analysis}

Data was analyzed using SPSS 14.0 statistical package for all variables. Descriptive statistics, including means and standard deviations (SDs) were used for categorical variables. Nonparametric statistics (Man-Whitney and Kruskal-Wallis) were used to examine daily activity time (DAT) among sex, the difference among sex and total steps per minute, and activity type related to steps per minute, respectively. A Tukey HSD post hoc analysis was used to determine steps per minute across physical education activities for all students. A p value less than .05 was used as the determining criteria for statistical significance.

\section{Results}

Two hundred and thirty-two $(\mathrm{n}=232)$ male and female middle school students participated in this study, 115 males and 117 females, respectively. All participants were currently enrolled in either sixth, seventh or eighth grades at the time of the study. Males and females were similar in regards to academic school standing and ethnicity. All participants self-identified their ethnicity as White, Non-Hispanic. 
Daily Activity Time (DAT) did not differ significantly among sex $[\mathrm{F}(1,7946.264)=2.227, \mathrm{P}=.136]$, but $\mathrm{did}$ differ significantly between activities [F (4, 43784.706) $=12.270, \mathrm{P}=.001]$. Table 1 presents the activity, total steps per minute, mean and standard deviation. A Man-
Whitney Test was conducted to evaluate the difference among sex and total steps per minute. The MannWhitney test showed that boys and girls do not appear to differ in their reported levels of steps per minute $(\mathrm{z}=$ $-1.869, \mathrm{p}>.05)$.

Table 1. Means and Standard Deviations for Action Type and Total Steps Per Minute.

\begin{tabular}{lcc}
\hline Activity & Total Steps Per Minute & Mean and Standard Deviation \\
\hline Basketball & 303 & $85.6640 \pm 35.49$ \\
Volleyball & 206 & $111.6704 \pm 106.45$ \\
Indoor Soccer & 769 & $100.8796 \pm 21.69$ \\
Pickle Ball & 414 & $112.3899 \pm 73.69$ \\
Fitness Activities & 145 & $112.9599 \pm 92.73$ \\
\hline
\end{tabular}

Figures 1, 2, and 3 illustrate the relationship between total steps per minute and basketball, volleyball, indoor soccer, pickle ball, and fitness activities.
Figure 1. Estimated Marginal Means of Steps Per Minute (SPM) Between Gender ( $0=$ Males) (1=Females).

\section{Figure 1 Estimated Marginal Means of spm}

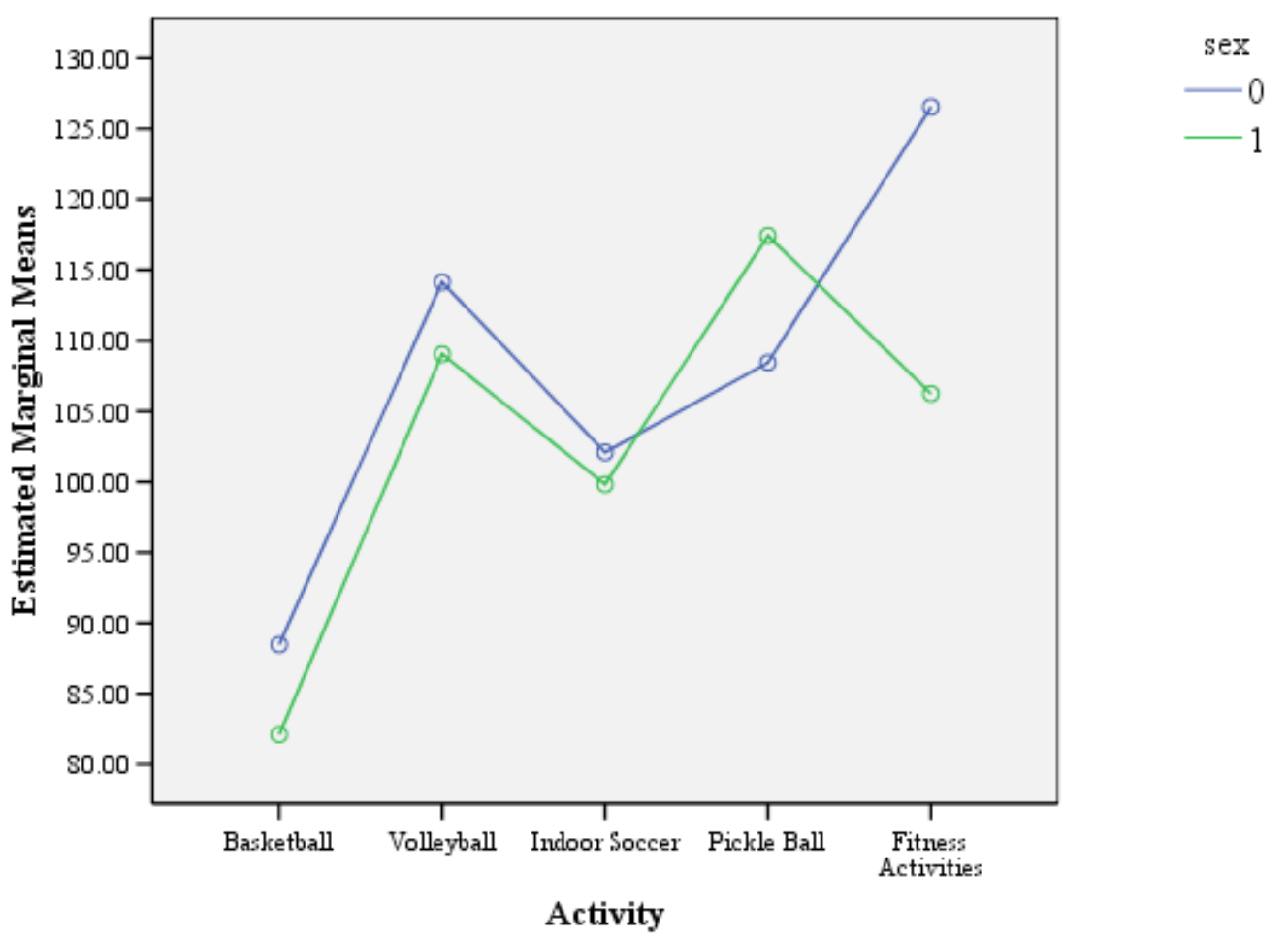


Figure 2. Average Steps Per Minute for Males $(\mathrm{n}=914)$ and Females $(\mathrm{n}=913)$.

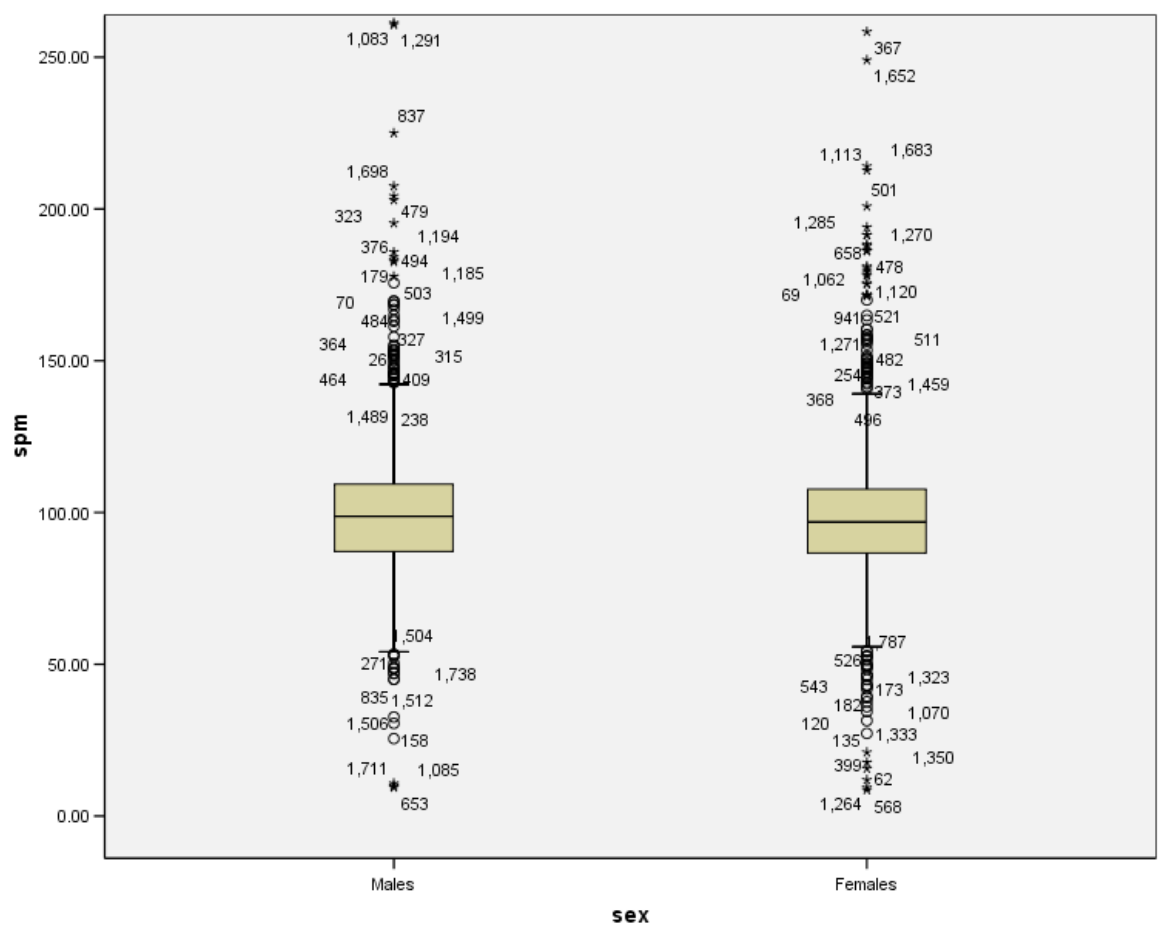

A Kruskal-Wallis test was also conducted and indicated that the type of activity students participate in affects their steps per minute, $\chi^{2}(4, n=1837)=241.351$ $\mathrm{p} \leq .05$. Tukey HSD post hock analysis found a .01 level of significance when basketball was compared with volleyball, indoor soccer, pickle ball, and fitness activities.

Figure 3. Overall Average Steps Per Minute for Basketball, Volleyball, Indoor Soccer, Pickle Ball, and Fitness Activity.

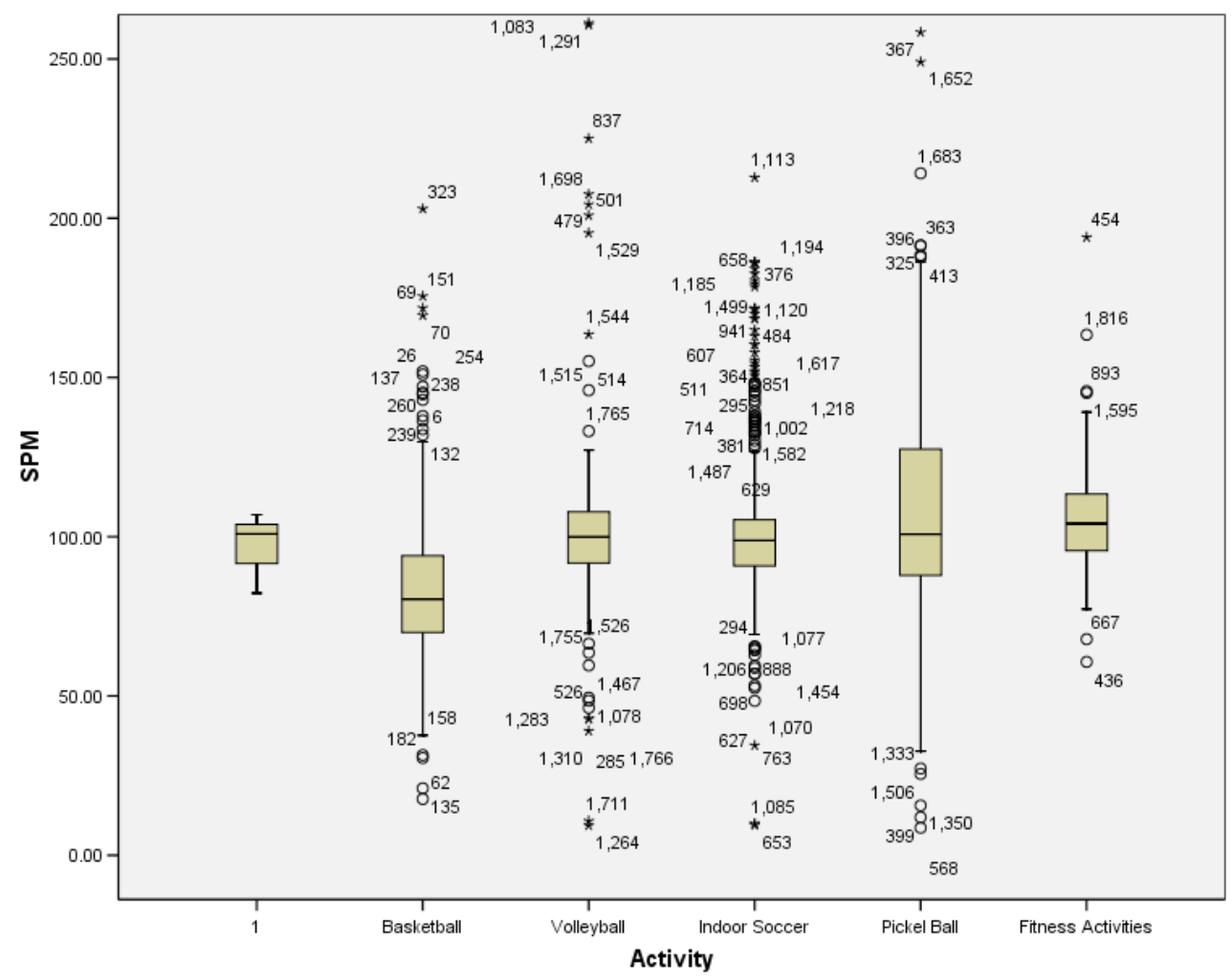


In reviewing the average steps per minute obtained in five curriculum units (basketball, volleyball, indoor soccer, pickle ball, and fitness activities) during an average 36 minute timeframe, only $1 \%-6 \%$ of the overall minimum 12,000 steps per minute reported as appropriate for healthy children were achieved. Table 2 presents each activity, the average number of steps for each activity and the calculated number of additional minutes and hours a child would still need to be active to reach the recommended 12,000 to 16,000 steps per day range.

Table 2. Activity, Average Number of Steps for Each Activity, and Calculated Number of Additional Minutes and Hours to Achieve the Recommended 12,000 to 16,000 Steps Per Day Range.

\begin{tabular}{lccc}
\hline Activity & $\begin{array}{c}\text { Average Total Steps Per } \\
\text { Minute }\end{array}$ & $\begin{array}{c}\text { Minutes / Hours } \\
\text { to Obtain 12,000 Steps }\end{array}$ & $\begin{array}{c}\text { Minutes / Hours } \\
\text { to Obtain 16,000 Steps }\end{array}$ \\
\hline Basketball & 303 & $1,428.5 \mathrm{~min} / 23.8 \mathrm{hours}$ & $1,904.8 \mathrm{~min} / 31.7$ hours \\
Volleyball & 206 & $2,105.3 \mathrm{~min} / 35.1$ hours & $2,807.0 \mathrm{~min} / 46.8$ hours \\
Indoor Soccer & 769 & $560.7 \mathrm{~min} / 9.3$ hours & $747.7 \mathrm{~min} / 12.5$ hours \\
Pickle Ball & 414 & $1,043.5 \mathrm{~min} / 17.4$ hours & $1,391.3 \mathrm{~min} / 23.2$ hours \\
Fitness Activities & 145 & $2,790.7 \mathrm{~min} / 46.5$ hours & $3,730.9 \mathrm{~min} / 62.0$ hours \\
\hline
\end{tabular}

\section{Discussion}

The purpose of this study was to compare steps per minute from five different curriculum units (basketball, volleyball, indoor soccer, pickle ball, and fitness activities) presented middle school physical education classes and how physical education step counts compared to obtaining the recommended 12,000 to 16,000 steps per day for healthy children.

Overall, physical education classroom activities such as basketball, volleyball, indoor soccer, pickle ball, and fitness activities, measured during a 36 minute class timeframe, accounted for approximately $1 \%-6 \%$ of the overall minimum 12,000 steps per minute reported as appropriate for healthy children. When observing the number of steps students are accumulating during physical education class time, physical educators need to be mindful of keeping students active. One of the most common ways physical educators negatively affect students' step counts in class time is during instructional transitions. Darst \& Pangrazi (2002) have stated that instructional transitions involve a change in instructional focus that, in turn, demands a reorganization of the class. Many times when students finish one activity and are moved into another activity, valuable time is lost promoting activity step counts. This is exhibited as students are viewed standing around waiting to begin a particular assignment.
Through proper preparation and planning from the middle school physical educator, students can continue to be active without losing time or steps. This can be done by having a well planned lesson plan with specific activities prepared with designated amounts of time set aside for each activity. Another pedagogical practice instructors can implement in their teaching, allowing students to continue in activity without losing time or steps, is to set out the equipment to use on the parameter of the gymnasium (Darst \& Pangrazi, 2002).

Data from this study are only comprised from the number of steps recorded during 36 minutes of activity time during a physical education classroom session. Steps taken during the rest of a child's day were not recorded and/or measured. An important point to note that a child's physical activity level should not rest solely on what is achieved during a physical activity course, regardless of the course structure or content, but should be incorporated, and used as an educational tool for school teachers, administrators, a child's family, and the child, into a child's overall daily activity.

When analyzing data from these curriculum units, across activities and gender, two overall insights were gleaned learned from middle school student's steps per minute during physical education class. 
First, males and females were very similar in the number of steps taken per minute. It was reported that males engaged in $4 \%$ more physical activity than the females, resulting in 1.5 increase in minutes of physical activity among the males (Scruggs, 2007). Also, it was found middle school males were generally (i.e., across all grade levels) more active than females (Trost, Russell, Sallis, Freedson, Taylor, Dowda, \& Sirad, 2002). Second, when looking at each activity, the activities that require more movement have the most steps per minute. While this may be familiar, middle school physical educators can take this information to better help plan lessons that increase or maximize the most steps per minute for their students. This also will benefit students, for the fact that they will have more opportunities to have increased physical activity. It has been suggested that middle school students prefer to participate in team sport activities (Barney \& Deutsch, 2010; Luke \& Cope, 1994 \& Tannehill, Romar, O'Sullivan, England, \& Roseburg, 1994). Thus with this preference to team sports and also if a middle school physical educator's goals is to get their students in activity the majority of the class time, they may refer to these team sports to reach desired results.

\section{Conclusion}

Data revealed that volleyball and fitness activities were the lowest steps per minute activities. With this being the case, physical educators may need to review ways to modify these activities. Typically, volleyball and fitness activities tend to have students standing and waiting to participate, thus decreasing their step count. The physical educator can modify these activities to increase steps per minute taken. For example, students can do jumping jacks or line jumps between points during their volleyball match. Something similar can also be modified for students participating in fitness activities. The data can serve as a beneficial guide when setting up unit or lesson plans in these two curriculum units, in regards to implementing specific, structured class activities for all the students. The data can also help guide the physical education teachers' preparation in designing activities, which will promote maximum activity patterns in the class (Barney, Mauch, \& Pleban, 2008). The teachers can also use this data for the purpose of eliminating the students standing around during these activities, thus resulting in increased student step counts.

Another method that middle school physical educators can utilize is the Internet or a teachers' website.
Wilkinson and Schneck (2003) found that parents responded favorably to a physical educators' website that kept them informed about their child's physical education class activities. Here middle school physical educators can use a website that can encourage, inform and educate parents regarding the importance of having their child be active to reach the goal of 12,000 steps a day.

This study is preliminary in nature and other studies may follow along these parameters; investigating steps per minute with high school students and lifetime activities (e.g., golf, tennis, racquetball, and badminton). Finally, other studies may be conducted to measure steps per minute achieved throughout the course of a child's day, as to better gauge appropriate school physical education guideline and curricula for a healthy youth to obtain the recommended 12,000 to 16,000 steps per day.

\section{Limitations}

Limitations of the current study include the possibility of self-report bias in regards to the recording of students' number of step counts on their student record sheet. Without a secondary check by the physical education instructor or investigator, the number of step counts could have been incorrectly entered or inflated. Data may therefore be limited, especially because of incomplete or inconsistent recording (e.g., missed class sessions by the student). An additional limitation of the current study is the inability to generalize these findings to other middle school students in other parts of the country. Due to the use of a sample of convenience from one middle school physical education class, further generalization of this data must be approached cautiously. Further study should be done utilizing multiple middle school physical education classes at different schools and in different regions of the country to explore the reproducibility of the process and findings.

\section{References}

Barfield, J.P., Rowe, D.A., \& Michael, T.J. (2004). Interinstrument consistency of the yamax digiwalker pedometer in elementary school-aged children. Measurement in Physical Education and Exercise Science, 8(2), 109-116.

Barney, D., \& Deutsch, J. (2010). The effects of middle school physical education curriculum on student attitudes. Asian Journal of Physical Education \& Recreation, 15(1), 12-20. 
Barney, D., Mauch, L., \& Pleban, F. (2008). Measuring pedometer step counts in four curriculum units in middle school physical education. ICHPER $* S D$ Journal of Research in Health, Physical Education, Recreation, Sport \& Dance, III, 43-47.

Beighle, A., \& Pangrazi, R.P. (2006). Measuring children's activity levels: The association between step-counts and activity time. Journal of Physical Activity and Health, 1(3), 1-14.

Beighle, A., Pangrazi, R.P., \& Vincent, S.D. (2001). Pedometers, physical activity and accountability. Journal of Physical Education, Recreation and Dance, 72, 16-19, 36.

Committee on Prevention of Obesity in Children and Youth. (2005). Preventing childhood obesity: Health in the balance. Washington, DC: Institute of Medicine: Author.

Corbin, C.B., \& Pangrazi, R.P. (2004). Physical activity for children: A statement of guidelines for children ages 5-12 (2nd ed.). Reston. NASPE Publications.

Darst, P.W., \& Pangrazi, R.P. (2002). Dynamic physical education for secondary students (4th ed.). San Francisco, CA: Benjamin Cummings.

Easton, R.G., Rowlands, A.V., \& Ingledew, D.K. (1998). Validity of heart rate, pedometry, and accelerometry for predicting the energy cost of children's activities. Journal of Applied Physiology, 84, 364-371.

Hatano, Y. (1993). Use of pedometer for promoting daily walking exercise. International Council of Health, Physical Education \& Recreation, 28, 4-8.

Hellmich, N. Journey to better fitness starts with 10,000 steps. (1999) USA Today. June 29, 1.

Jain, A. (2004). What works for obesity? A summary of the research behind obesity interventions. London: BMJ Publishing Group.

Luke, M.D., \& Cope, L.D. (1994). Students attitudes toward teacher behavior and program content in school physical education. The Physical Educator, 51,(2), 57-66.
Ogden, C.L., Carroll, M.D., \& Curtin, L.R. (2006). Prevalence of overweight and obesity in the united states. Journal of American Medical Association, 295, $1549-1555$

Pangrazi, R.P., \& Corbin, C.B. (1990). Physical fitness: Questions teachers ask. Journal of Physical Education, Recreation and Dance, 61(7), 14-19.

Pate, R.R., Davis, M.G., Robinson, T.N., Stone, E.J., McKenzie, T.L., \& Young, J.C. (2006). Promoting physical activity in children and youth: A leadership role for schools. Circulation, 114, 1214-1224.

Tudor-Locke, C.E., \& Myers, A. M.(2001). Methodological considerations for researchers and practitioners using pedometers to measure physical (ambulatory) activity. Research Quarterly for Exercise and Sport, 72, 1-12.

Scruggs, P.W. (2007). Middle school physical education physical activity quantification: A pedometer steps/min guideline. Research Quarterly for Exercise and Sport. 78, 284-292.

Tannehill, D., Romar, J.E., O’Sullivan, M., England, K., \& Rosenburg, D. (1994). Attitudes toward physical education: Their impact on how physical education teachers make sense of their work. Journal of Teaching in Physical Education, 13, 406-420.

Trost, S.G., Russell, R.R., Sallis, J.F., Freedson, P.S., Taylor, W.C., Dowda, M., \& Sirard, J. (2002). Age and gender differences in objectively measured physical activity in youth. Medicine \& Science in Sport Exercise, 34, 350-355.

Vincent, S.D., \& Pangrazi, R.P. (2002) Does reactivity exist in children when measuring activity levels with pedometers? Pediatric Exercise Science, 14, 56-63.

Welk, G.J., Corbin, C.B., \& Dale, D. (2000). Measurement issues in the assessment of physical activity in children. Research Quarterly for Exercise and Sport, 71, 59-73.

Wilkinson, C., \& Schneck, H. (2003). The effects of a school physical education and health web site on parental knowledge of the program. The Physical Educator, 162-168. 